\title{
PELATIHAN APLIKASI GOOGLE FORM@ SEBAGAI MEDIA EVALUASI PEMBELAJARAN DI SMP NEGERI 1 CERENTI
}

\author{
Walhidayat $^{1}$, Susi Handayani' ${ }^{2}$, Mariza Devega² \\ ${ }^{123}$ Universitas Lancang Kuning, Riau, Indonesia \\ email: walhidayat@unilak.ac.id ${ }^{1}$, susi@unilak.ac.id², mariza@unilak.ac.id ${ }^{3}$
}

\begin{abstract}
Abstrak: Proses pembelajaran di sekolah merupakan suatu rutinitas penting dalam beberapa poin kehidupan. Pendidikan adalah hak bagi seluruh warga negara, sebagaimana tertuang dalam Undang Undang Republik Indonesia Tahun 1945 sesuai dengan pasal 31 yang berbunyi "(1) Setiap warga negara berhak mendapat pendidikan, (2) Setiap warga negara wajib mengikuti pendidikan dasar dan pemerintah wajib membiayainya". Merujuk pada poin penting tersebut proses pendidikan disekolah dapat dilakukan dalam beberapa alur: siswa mendaftar kemudian belajar dan lulus dari sekolah yang tempat menimba ilmu. Tidak hanya meluluskan siswa yang berkualitas dengan tenaga pendidik yang mumpuni dan proses pembelajaran yang terstruktur dan terukur. Input atau pun calon siswa yang akan menempuh pendidikan pada sekolah sedapat mungkin merupakan bibit unggul yang memiliki potensi.
\end{abstract}

Kata Kunci: Pelatihan guru, Aplikasi Google Form, Evaluasi Pembelajaran

Abstract: The learning process at school is an important routine in several points of life. Education is a right for all citizens, as stated in the 1945 Constitution of the Republic of Indonesia in accordance with article 31 which reads "(1) Every citizen has the right to education, (2) Every citizen is obliged to attend basic education and the government is obliged to finance it". Referring to this important point, the education process in schools can be carried out in several ways: students register and then study and graduate from schools where they gain knowledge. Not only graduating quality students with qualified educators and a structured and measurable learning process. Inputs or prospective students who will study at school as far as possible are superior seeds that have potential

Keywords: Teacher training, Google Form Application, Learning Evaluation

\section{Pendahuluan}

\section{Analisis Situasi}

Proses pembelajaran di sekolah merupakan suatu rutinitas penting [1] dalam beberapa poin kehidupan. Pendidikan adalah hak bagi seluruh warga negara, sebagaimana tertuang dalam Undang Undang Republik Indonesia Tahun 1945[2] sesuai dengan pasal 31 yang berbunyi "(1) Setiap warga negara berhak mendapat pendidikan, (2) Setiap warga negara wajib mengikuti pendidikan dasar dan pemerintah wajib membiayainya". Merujuk pada poin penting tersebut proses pendidikan disekolah dapat dilakukan dalam beberapa alur: siswa mendaftar kemudian belajar dan lulus dari sekolah 
yang tempat menimba ilmu. Tidak hanya meluluskan siswa yang berkualitas dengan tenaga pendidik yang mumpuni dan proses pembelajaran yang terstruktur dan terukur. Input atau pun calon siswa yang akan menempuh pendidikan pada sekolah sedapat mungkin merupakan bibit unggul yang memiliki potensi.

Potensi calon siswa yang akan mendaftar pada sekolah yang di tuju dapat di lihat dari nilai hasil proses belajar seperti salah satunya nilai rapor per semester, sertifikat atau piagam / sertifikat yang didapat atau pun dari sumber berita yang dapat di validasi. Dalam mendukung proses transfer ilmu antara guru dan siswa perlu disiasati, apalagi pandemic Covid-19 yang melanda mengharuskan para Guru agar selalu siap dalam melakukan proses pembelajaran walaupun tidak dalam bentuk tatap muka (secara langsung). Maka untuk melakukan pengukuran / evaluasi pemahaman murid terhadap materi yang disampaikan, sekiranya guru dapat memanfaat teknologi informasi salah satunya adalah aplikasi gratis Google Forms (C)

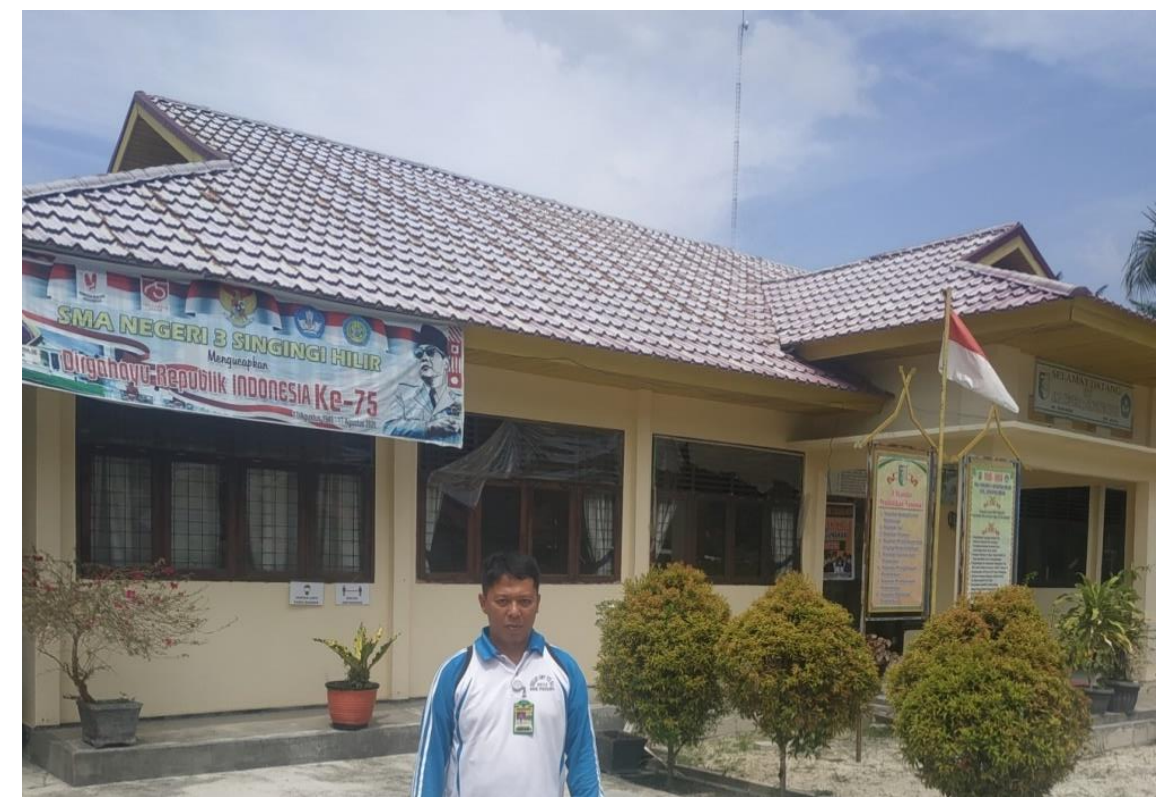

Gambar 1. Tim Pengabdian di Sekolah SMPN 1 Cerenti.

\section{Permasalahan Mitra}

Melihat perkembangan keadaan yang terkini, terkait dengan mewabahnya pandemi Covid-19. Sebagaimana di kutip dari berita Kompas.com Mei 2020 'JAKARTA, KOMPAS.com - Penularan Covid-19 di Indonesia terus terjadi sejak 2 Maret 2020. Berdasarkan data yang dihimpun hingga Rabu (13/5/2020) pukul 12.00, terjadi penambahan kasus baru positif Covid-19 sebanyak 689 orang. Dengan demikian, ada 15.438 kasus Covid-19 di Indonesia. Penambahan kasus baru ini merupakan penambahan kasus tertinggi di Indonesia. "Kasus konfirmasi positif yang kita dapatkan hari ini bertambah 689 orang, sehingga totalnya 15.438 orang,' ujar Juru Bicara Pemerintah untuk Penanganan Virus Corona Achmad Yurianto dalam konferensi pers pada Rabu sore."

Maka hal ini juga merubah perilaku kehidupan bermasyarakat di indonesia, secara keseluruhan karena pemerintah secara resmi mengeluarkan peraturan yang membatasi pola kehidupan sosial dan pembatasa interaksi fisik (social and phisical distancing).

Untuk menekan laju dan meminimalisir dampak penyebaran Virus Corona pemerintah pusat mengeluarkan berbagai peraturan seperti diantaranya Pembatasan Sosial Berskala Besar (PSBB). Dengan berlakunya peraturan tersebut sekolah-sekolah 
diliburkan akibat diliburkannya sekolah maka siswa guru maupun calon siswa tidak bisa datang ke sekolah untuk melakukan aktifitas seperti sedia kala.

Maka mengantisipasi proses umum yang dilakukan seperti musim sebelum pandemic siswa datang secara langsung untuk mengikuti proses pembelajaran disekolah, karena keterpaksaan maka disini sekolah SMPN 1 Singingi Hilir berinisiatif untuk melakukan pelatihan bagi guru bagaimana memanfaatkan aplikasi google Form untuk evaluasi pembelajaran siswa. Oleh karena keterbatasan pemahaman sumber daya sekolah SMPN 1 Cerenti meminta kepada instisusi yang dapat membantu melakukan pelatihan dan monitoring pelaksanaan PSB di bantu oleh tenaga ahli dari Universitas Lancang Kuning secara khususnya pada dosen Fakultas Ilmu Komputer.

\section{Metode}

\section{Kelayakan Sasaran Pengabdian}

Sasaran kegiatan pelaksanaan pengabdian ini adalah Guru SMA N 3 Singingi Hilir, yang telah di tunjuk oleh kepala sekolah. Adapun yang di berikan pelatihan pada program pengabdian ini adalah tenaga pendidik yang diangkat sebagai panitia. Panitia atau target pelatihan Google Forms ini adalah guru yang memiliki latar belakang keilmuan di bidang komputer, tetapi belum memahami beberapa aplikasi penunjang kegiatan pembelajaran.

\section{Prosedur Kerja}

Prosedur kerja pelaksanaan kegiatan ini dirancang sebagai berikut:

a. Melakukan tahapan pengusulan kegiatan Iptekspada Masyarakat ke LPPM, baik di unit Fakultas maupun di Lembaga.

b. Pengurusan kelengkapan administrasi .

c. Menghubungi secara formal kepada mitra kerja.

d. Mempersiapkan materi dan modul pelatihan.

e. Mempersiapkan peralatan pendukung kegiatan pelatihan

f. Melakukan perjalanan ke Lokasi mitra di Teluk Kuantan Kabupaten Kuantan Singingi

g. Pelatihan dan sosialisasi di Lokasi

h. Evaluasi pelaksanaan kegiatan

\section{Kelengkapan yang dibutuhkan}

Adapun peralatan merupakan penunjang kegiatan yang sangat dibutuhkan, rincian dan kegunaan adalah sebagai berikut:

a. Spanduk pelatihan ataupun standing banner, dibutuhkan sebagai informasi pelaksanaan kegiatan di lokasi mitra dan sebagai alat peraga dari kegiatan pelatihan yang ditujukan pada tenaga pendidik setempat.

b. Quisoner pra pelatihan dan pasca pelatihan sebagai bahan evaluasi pelaksanaan kegiatan.

c. Peserta diharuskan membawa laptop

d. Laptop dan Infokus sebagai perlengkapan presentasi.

e. Mempersiapkan salah satu akun Google untuk penempatan database Google Forms, dalam hal ini pemateri akan menggunakan akun Google smpn1cerenti@gmail.com. 
f. Berkas berita acara presensi peserta, pemateri dan tim pelaksana kegiatan.

g. Poster, sebagai media penambah informasi kegiatan pelatihan.

\section{Kepakaran Tim}

Pelaksanaan kegiatan pengabdian ini sudah sesuai dengan masing masing kompetensi tim pengabdian kepada masyarakat. Dimana topik pengabdian yang dibawa merupakan bidang yang sudah menjadi tanggung jawab dari tim pengabdian.

a. Penjabaran tentang materi pelatihan dan diskusi Google Forms, disampaikan oleh Walhidayat, M.Kom.

b. Mempersiapkan modul pelatihan dan memberikan saran kelengkapan pelatihan oleh Susi Handayani, M.Kom.

c. Persiapan administrasi kegiatan pelatihan Ipteks bagi masyarakat oleh Mariza Devega, S.Tsi, M.Kom

\section{Hasil Dan Pembahasan}

Pengabdian kepada masyarakat ini dilakukan berdasarkan hasil kesepakatan bersama mitra (guru sekolah) bahwa yang ikut pelatihan adalah guru beserta staf sekolah, hal ini dikarenakan antusias civitas dilingkungan SMP N 1 Cerenti dalam menggali ilmu dan pemahaman pada penggunaan teknologi yang membantu proses belajar dan mengajar pada masa pandemic ini.

Pelaksanaan kegiatan dilakukan pada:

\begin{tabular}{|c|c|}
\hline Hari & : Kamis \\
\hline Tanggal & : 2 April 2021 \\
\hline Waktu & : 09.00 s.d 12.00 \\
\hline Tempat & $\begin{array}{l}\text { : - Ruangan Rapat sekolah yang di tempati oleh Guru. } \\
\text { - Pemateri memberikan pelatihan melalui daring via zoom }\end{array}$ \\
\hline
\end{tabular}

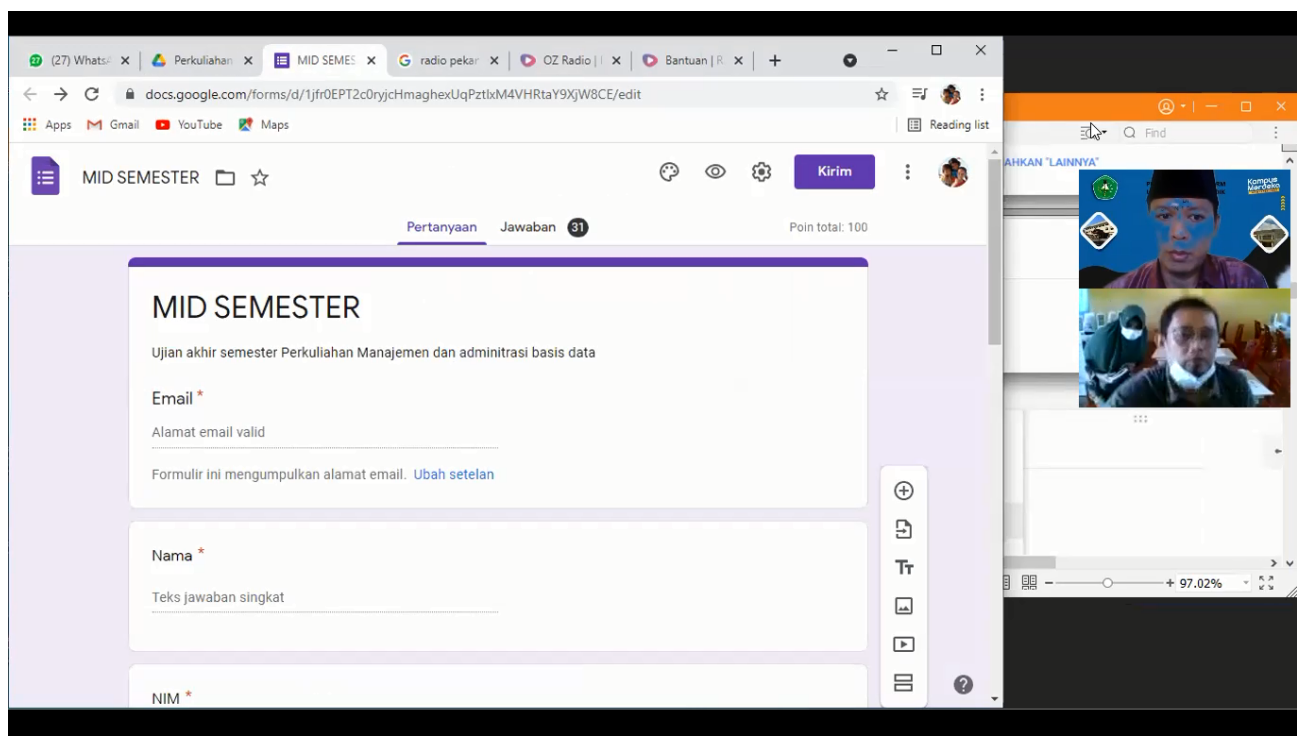

Gambar 2. Pelaksanaan pelatihan GForm 


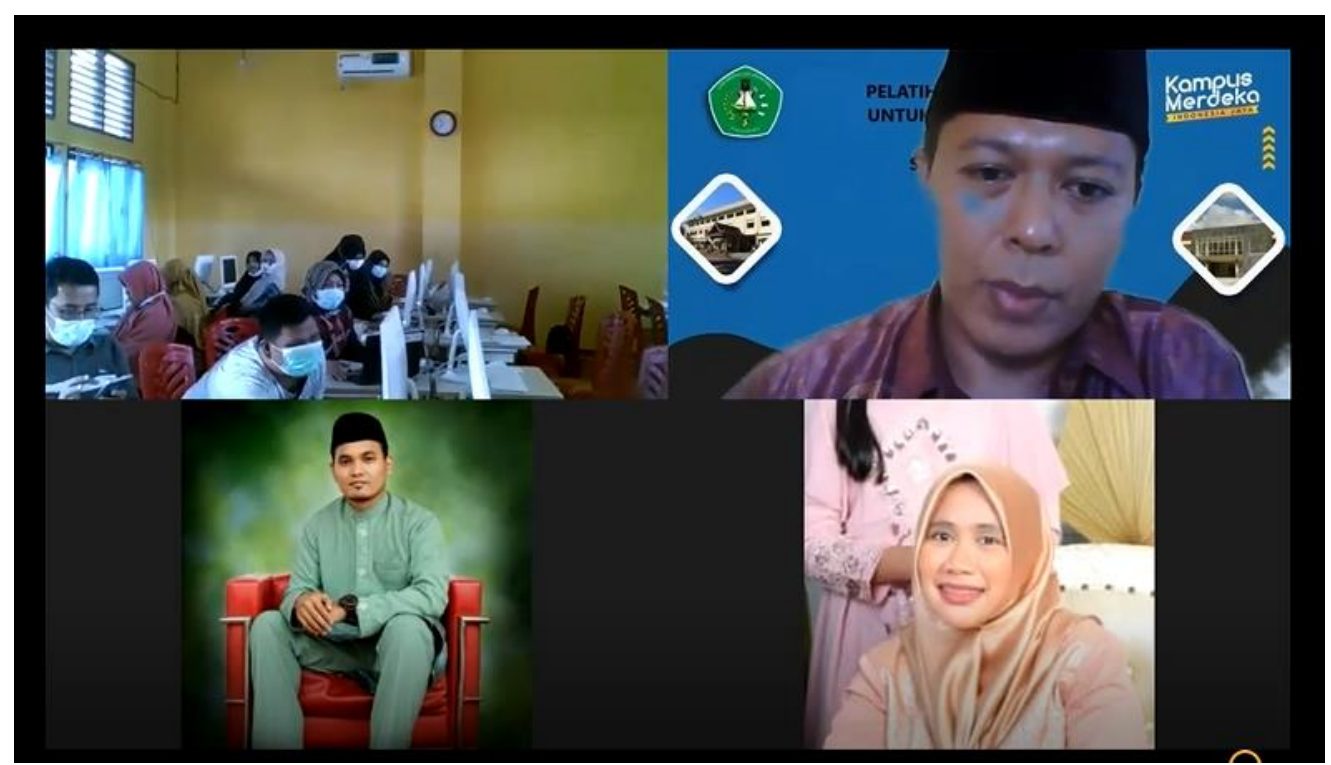

Gambar 3. Peserta pelatihan GForm

\section{Tingkat Pemahaman Peserta setelah melakukan pelatihan}

Berdasarkan hasil survey pasca pelatihan yang telah dilaksanakan di Sekolam menengah Pertama Negeri 1 Cerenti. Dimana kuisoner diberikan kepada sebanyak 12 orang tenaga pendidik dan tenaga kependidikan yang ikut serta berpartisipasi dalam sesi pelatihan tersebut, dapat disimpulkan bahwa peserta memahami penjelasan yang diberikan oleh tutor dan dapat meng implemetasikan ilmu dalam praktik pembuatan soal / quiz dan melakukan rekaitulasi penilaian siswa secara keseluruhan.

Tabel 1. Survey Hasil Pelatihan GForm Untuk Guru di SMPN 1 Cerenti

\begin{tabular}{|c|c|c|c|}
\hline NO & $\begin{array}{c}\text { DESKRIPSI JENIS AKTIVITAS } \\
\text { PELATIHAN }\end{array}$ & $\begin{array}{c}\text { TINGKAT } \\
\text { PEMAHAMAN } \\
\text { PESERTA } \\
\end{array}$ & KETERANGAN \\
\hline 1 & Mengenal aplikasi Google Form & $98 \%$ & $\begin{array}{c}\text { Semua Guru } \\
\text { mengenal aplikasi } \\
\text { online GForm }\end{array}$ \\
\hline 2 & Membuat Soal / Quiz di GForm & $80 \%$ & $\begin{array}{l}\text { Kendala bagi sisa } \\
20 \% \text {, adalah } \\
\text { memahami menu } \\
\text { yang di sediakan }\end{array}$ \\
\hline 3 & $\begin{array}{l}\text { Memberikan penilaian (bobot) pada } \\
\text { setiap butir pertanyaan }\end{array}$ & $80 \%$ & - \\
\hline 4 & $\begin{array}{c}\text { Menyebarkan (share link) dokumen } \\
\text { Gform }\end{array}$ & $100 \%$ & - \\
\hline 5 & $\begin{array}{l}\text { Melihat respon dari para responden } \\
\text { yang mengirimkan tugas di GForm }\end{array}$ & $80 \%$ & - \\
\hline 6 & Rekapitulasi nilai & $70 \%$ & $\begin{array}{c}\text { Kendala bagi yang } \\
\text { kurang paham adalah } \\
\text { konversi ke dokumen } \\
\text { spreadsheet. }\end{array}$ \\
\hline
\end{tabular}




\section{KESIMPULAN}

Berdasarkan hasil pelaksanaan kegiatan Ipteks bagi Masyarakat (IbM) yang di taja oleh Dosen Fakultas Ilmu Komputer Unuversitas Lancang Kuning, dengan memberikan pelatihan dan update pemahaman teknologi informasi yang terbaru, dapat memberikan kemudahan sebagai alternatif proses pembelajaran di sekolah formal khususnya SMP N 1 Cerenti Kabupaten Kuantan Singingi - Riau. Sebanyak 12 orang Guru dan tenaga kependidikan dapat memanfaatkan aplikasi online Google Form ${ }^{\circledR}$ dengan menggunakan Google Formulir sebagai bahan evaluasi pembelajaran.

\section{Ucapan Terima Kasih}

Penulis mengucapkan terima kasih kepada dekan Fakultas Ilmu Komputer beserta jajaran yang telah memberi dukungan pembiayaan dan sarana terhadap pengabdian ini, sehingga kegiatan ini dapat dilaksanakan dengan baik.

\section{DAFTAR PUSTAKA}

Dewan Perwakilan Rakyat Indonesia, "Undang-Undang (UU) tentang Guru dan Dosen Nomor 14," Dewan Perwakilan Rakyat Indones., p. 2, 2005, [Online]. Available: https://www.google.com/url?sa=t\&rct=j\&q=\&esrc=s\&source=web\&cd=1\&cad=rja \&uact $=8 \&$ ved $=2$ ahUKEwjWxrKeif7eAhVYfysKHcHWAOwQFjAAegQICRAC\&url=https \%3A\%2F\%2Fwww.ojk.go.id\%2Fid\%2Fkanal\%2Fpasarmodal\%2Fregulasi\%2Fundang-undang\%2FDocuments\%2FPages\%2Fundangundang-nomo.

F. Sidik and M. Rahmawati, "Perancangan Sistem Informasi Pendaftaran Siswa Baru Berbasis Web Pada SMK Bina Putra Jakarta," Paradigma, vol. 20, no. 2, p. 1, 2018.

I. Handayani, Q. Aini, N. Cholisoh, and I. I. Agustina, "Pemanfaatan Google Form Sebagai Pendaftaran TOEFL (Test Of English as a Foreign Language) Secara Online.," J. Teknoinfo, vol. 12, no. 2, p. 55, 2018, doi: 10.33365/jti.v12i2.73.

M. Iqbal, R. Rosramadhana, B. K. Amal, and M. E. Rumapea, "Penggunaan Google Forms Sebagai Media Pemberian Tugas Mata Kuliah Pengantar Ilmu Sosial," Jupiis J. Pendidik. IImu-IImu Sos., vol. 10, no. 1, p. 120, 2018, doi: 10.24114/jupiis.v10i1.9652.

M. P. Susana Eviani, Syafrika Deni Rizki, "Sistem Informasi Penerimaan Siswa Baru Berbasis Web Pada Smpn 34 Kabupaten Tebo," Univ. Putra Indones. YPTK Padang, no. 1, pp. 1-7, 2016.

Republik Indonesia, "Perubahan ke IV Undang-Undang Dasar Negara Republik Indonesia Tahun 1945," no. 1, pp. 1-6, 2002. 